\title{
Three languages of instruction in Fryslân
}

\author{
DURK GORTER
}

\section{Abstract}

Three languages play an important role in the province of Fryslân: Frisian as the minority language spoken by a majority of the population, Dutch as the dominant language in society, and English as an increasingly important additional language. The position of Frisian as a language for teaching is marginal at all levels of education. Although it is an obligatory language for all primary schools, there is only a small percentage of schools that use Frisian as a medium of instruction. Even when attitudes toward Frisian seem positive, English and in particular Dutch are perceived as more important languages to learn. A promising experiment with trilingual education has shown the possibilities for using three languages as languages of instruction. Multilingualism in the curriculum is an important challenge for education in Fryslân.

\section{Introduction}

The province of Fryslân (Friesland) is located in the northwestern part of the Netherlands. The area has never in history been a homogeneous monolingual area. Historical linguists date the coming into existence of the Frisian language between the fourth and sixth centuries, when Frisian began to separate itself gradually from other Germanic languages (Bremmer 1997). There are no written sources in Frisian from those times, just a few references in outside sources and a few runic inscriptions (Nielsen 1994). During the seventh and eighth centuries, the Frisians had their "golden age" and were seafarers who roamed all over the coasts of the North Sea and Scandinavia (Lebecq 1994). In those days, other languages must have played a role in the Frisian lands.

During the period when the most common language of administration was Old Frisian, roughly between 1300 and 1500, Frisian was never the 
only written language. Many scribes were trained how to write outside Fryslân and they must have been multilingual in at least Frisian, Dutch, and Latin (Vries 1997). After 1500, Fryslân became integrated with the rest of the Netherlands. During the sixteenth century, many new civil servants and traders came to the province, bringing new languages with them, particularly forms of early Dutch. Due to this intensified language contact, a number of town dialects arose in the seven major towns of Fryslân. These so-called "town Frisian" dialects are still spoken in twentyfirst-century Fryslân, although they are declining and are being replaced little by little by standard Dutch.

Until the nineteenth century, there were, broadly speaking, three types of school. The "Latin schools" prepared students for university education, and at the "French schools" pupils learned arithmetic and languages as important skills for trade and commerce. The "Duytsche" (Dutch) schools were for children from the lower and middle classes to learn the basics of the state language.

From the beginning of the nineteenth century, the province of Fryslân became firmly integrated into the Kingdom of the Netherlands. Primary education became widely available, although it took until 1900 before general compulsory education was introduced. After the introduction of the law on secondary education in 1863, a new type of secondary school, HBS (Higher Citizens School) was established. The learning of "modern languages," that is, English, French, and German, was an important part of the curriculum. A well-educated citizen was supposed to command these three foreign languages. They were, of course, also the three most important languages for the Netherlands as a trading nation. The Dutch standard language had gradually become the dominant language for the "higher functions" of social life, not only education, but also the church, the economy, and public administration.

The beginnings of the Frisian movement can be traced back to the nineteenth century (Zondag 1993). The movement only began to demand a place for Frisian in education from the early twentieth century onward. In 1907, the first Frisian lessons were organized outside regular school hours. In 1937, Dutch primary school law was changed in order to allow for the teaching of some Frisian during the regular hours for the teaching of Dutch (De Jong and Riemersma 1994; Zondag 1982).

Since the second half of the twentieth century, Dutch in Fryslân has further strengthened its position as dominant language in society in many ways. This happened because more students participated in secondary and tertiary education, through better means of transportation, travel and tourism, and because of the general availability of telephone, radio, and, since the 1960s, television. Frisian remained as a spoken language 
for the informal domains mainly in the countryside. The influence of these social changes plus an increased migration of the population has gradually changed the language relationships between Frisian, the dialects, and Dutch. English, as an additional language, has become more important over the last few decades. Today, the sociolinguistic position of English is more that of a second language than of a foreign language.

\section{Sociolinguistic situation}

On the basis of large-scale language surveys carried out in 1967, 1980, and 1994, it is known that $74 \%$ of the population are able to speak Frisian (Pietersen 1969; Gorter et al. 1984; Gorter and Jonkman 1995). This implies roughly 400,000 speakers of Frisian (the total population of Fryslân was 634,000 in 2002). The survey results also indicate that $94 \%$ of the population can understand Frisian, $65 \%$ can read it, and only $17 \%$ can write the language.

Overall, these percentages have appeared to be stable over a period of 25 years, although there is a slow decline in speaking proficiency and a slight increase in writing abilities.

From the surveys it is also known that $55 \%$ of the population has Frisian as its first language. Almost 20\% are second-language learners, which is an indication of the vitality of Frisian. The language is transmitted to the next generation on average by some $80 \%$ of the mother-tongue parents. Frisian also recoups slightly because there are Dutch mothertongue speakers and dialect speakers who raise their children through Frisian. Among the younger age cohorts, born after 1990, Frisian as first language is learned only by some $40 \%$, thus, in the longer run, the percentage of mother-tongue speakers will slowly decrease. Moreover, all Frisian-speakers are bilingual, because they are able to speak, read, and write Dutch. There are no monolingual Frisian-speakers in an absolute sense. This does not imply that bilingualism is completely balanced. About $60 \%$ of the mother-tongue speakers claim to have greater oral fluency in Frisian than in Dutch.

The distribution of the use of Frisian over different social domains shows an uneven pattern. In the domains of the family, work, and the community, Frisian holds a relatively strong position, because a majority of the population habitually uses Frisian. In the villages and the countryside, people are exposed to Frisian every day (as they are also exposed to Dutch and even to English, the latter mainly through television). In the larger towns (over 20,000 inhabitants) people may not get exposed to Frisian all that much. Of course, about one quarter of the population of the 
capital of Ljouwert speaks Frisian at home and one may overhear Frisian spoken in the streets, but it is not uncommon for children from nonFrisian-speaking homes to know hardly any Frisian at all.

The Frisian language has been officially recognized as the second language of the Netherlands. That recognition has entailed moderate promotion of the language by the state, which has been arranged in a formal agreement between the state and the province (Bestuursafspraak 2001). This covenant has the same structure and the same paragraphs as the European Charter for Regional or Minority Languages of the Council of Europe - ratified by the Netherlands in 1998. It includes provisions for education, media, culture, and scientific research, as well as for public administration and the use of Frisian in the courts. For Frisian language activists the ratification of the charter was important, because it has become more difficult to reverse existing measures.

Today, Frisian is allowed to be used legally in almost all circumstances but other mechanisms, such as traditions, attitudes, or rules of politeness, often constrain the use of this minority language. It is clear that the older more strict "division of functions" between Frisian and Dutch has evolved into a new pattern. Dutch has entered into the intimate spheres of the home, friends, family and neighborhood. At the same time, Frisian makes efforts to conquer a small part of the higher domains of mass media, public administration, and education (Gorter et al. 2001).

After the Frisian-speakers, the second largest language group are the Dutch-speakers (33\%). There are also mother-tongue speakers of dialectal varieties (town Frisian, Stellingwerfs, Bildts), a total of approximately $11 \%$. Language transmission among the dialect speakers has decreased sharply over the last two generations. Over the last decade, the number of immigrants from other countries has increased, and thus the number of foreign-language mother-tongue speakers has been augmented. It has been estimated that approximately 25,000 foreign-born migrants settled in Fryslân between 1990 and 1999 (Van der Vaart 2001: 15), a number which constitutes $3 \%$ of the total population. A large part of them settle in the four largest towns. For the capital Ljouwert (population 90,000), it was established that some fifty different mother tongues were spoken by primary-school children (Van der Avoird et al. 1999). The five most common foreign mother tongues were English, Arabic, Kurdish, Hindi, and Berber. These five together accounted for $50 \%$ of all speakers of foreign languages.

English plays an increasingly important role in Fryslân, similarly to the rest of the Netherlands and some other European countries. English has become part of the linguistic repertoire of average citizens (Eurobarometer 2001). All inhabitants of Fryslân are exposed to English in their daily 
lives. Nowadays, television is a powerful force for the socialization of all family members (Benton and Benton 2001: 429) and the TV set is "speaking English" a great deal of the time, because American or British programs are subtitled in Dutch, retaining the original sound track. Advertising commercials, including those on radio, or in newspapers and magazines, are often wholly or partly in English. In the "linguistic landscape," the signs in the streets, one sees English on billboards and in the names of shops, bars, restaurants, etc. In this way, everyone is confronted with English on a regular basis. English is no longer a foreign language for the average inhabitant of Fryslân but, in many ways, a second language. Overall, one can say that multilingualism has increased (Gorter 2001).

\section{Educational system and policy}

\subsection{Background information}

By way of introduction, summary statistics on the number schools and the number of pupils involved in the school system in the province of Fryslân are presented in Table 1 .

Students at all levels come from the province of Fryslân itself, except for the three higher tertiary education institutes, which attract a large number of their students from the rest of the Netherlands or from abroad. Since there is no university in Fryslân, students have to go to a different province for university training. For each level of education a brief sketch of the teaching and use of Frisian, Dutch, and other languages can be given.

Table 1. Summary statistics for education in Fryslân (2000)

\begin{tabular}{lcc}
\hline Type of education & Number of schools & Enrollment \\
\hline Preschool, including day-care & 258 & $8,000^{\mathrm{a}}$ \\
Primary & 495 & 62,000 \\
Special & 29 & 4,500 \\
Secondary & 49 & 37,000 \\
Vocational & 3 & 16,000 \\
Higher & 3 & 15,000 \\
Total & 836 & 142,500 \\
\hline
\end{tabular}

Source: Ytsma and Van der Schaaf (2001: 29); Fryslân yn sifers (2001: 8) (figures are rounded off).

a. estimate 
Playgroups (for children aged 2-4) are mostly privately initiated; they are supervised and partly financed by local government. A survey shows that most rural playgroups can be regarded as bilingual, while in urban playgroups Frisian is only used occasionally (Boneschansker and Le Rütte 2000). Since 1989, the "Pjutteboartersplak" association has started up seven Frisian playgroups, which aim at a wholly Frisian play environment for the young child. They have an enrolment of 200 children, which is about $3 \%$ of all children in this age group. In 2001, day-care centers were established for the first time, where parents since then have been able to choose between Dutch and Frisian as the language of communication with the children.

Primary schools are attended by children aged 4-12 (grades 1-8). All primary schools in Fryslân have the obligation to teach Dutch, Frisian and, in the two highest grades, English as well. As far as the teaching of Frisian is concerned there are no differences between public and private schools. The main difference is between the schools in the towns on the one hand and in the villages on the other. The number of schools that have a school population with a mixed language background has increased substantially over the last ten years - from $23 \%$ in 1981 to $47 \%$ in 1999 (Inspectie van het Onderwijs 2001). Schools hardly ever differentiate according to the language background of the children.

The most common pattern is to teach Frisian as a subject for one lesson (30-45 minutes) per week in grades $3-8$. This is equal to 240 lessons over a period of six years. The situation has hardly changed since 1980 when Frisian was introduced as a compulsory subject. It seems that schools were not encouraged over the past years to increase the number of hours of Frisian. The position of Frisian is also modest as a medium of instruction for other subjects. Only $16 \%$ of the schools use Frisian as medium of instruction for "social studies" (in grades 3-8). Of all schools, $56 \%$ report using Frisian as medium of instruction outside the Frisian lessons, although to a varying degree (Inspectie van het Onderwijs 2001: 24).

English is taught as a subject for one hour a week in the two highest grades, when the children are eleven and twelve years old. This is a general obligation in the Netherlands. At primary level it is exceptional for children to go abroad or be taught any extra-curricular English classes.

In an effort to stimulate the teaching of Frisian, not English, an experiment with trilingual education was set up in 1997. The educational advisory center (GCO-Fryslân), in cooperation with the Fryske Akademy, has developed a new model, which is essentially bilingual (Projektplan 1997). The educational center develops learning material for teaching Frisian as a medium of instruction and advises the schools. The Fryske Akademy 
tests the children every year on their language abilities and attitudes in Dutch, Frisian, and later, English. Seven schools from small villages with a total of approximately 400 pupils participate in the so-called Trilingual Schools Project (Ytsma 2000a, 2000b, 2002). In the model, 50\% of the teaching time is systematically given to Frisian and the other $50 \%$ to Dutch. In the last two grades, following the introduction of English as a subject in the sixth grade, $20 \%$ are taught through the medium of English as a third language. In practice this means that pupils have English as the medium of instruction during two afternoons per week. The goal is to meet the attainment targets for both Frisian and Dutch to the full extent (which is not the case at all in most other schools). Moreover, the pupils will have reached a basic communicative ability in English. The main difference with other schools that use Frisian as medium of instruction is in the systematic and equal division of both languages over teaching time. It is known that other bilingual schools use both languages less systematically. The use of English in this way is unique to the experiment (Ytsma 2002).

All types of secondary education have in common a period of two to four years of basic education ("basisvorming"). Its length varies and depends on the curriculum and the school level. The common curriculum has fifteen subjects, including general and technical subjects, but schools are free to vary how much they offer of each subject. Dutch and English are included in the curriculum in all schools. Other foreign languages that can be chosen in some school types are German and French. In gymnasium Greek and Latin are also taught. Thus, a number of children in the gymnasium may be taught no less than seven different languages as school subjects.

Most secondary schools have limited Frisian to the first year, for one hour a week, which is about as minimal as possible. About one third of the schools in Fryslân have asked for an exemption from this legal obligation because they lack qualified teachers.

Frisian has the status of optional subject in the higher grades of secondary education. Few students take Frisian as a subject in their final exams, although the numbers have increased substantially following recent changes in the curriculum. English as an exam subject is chosen by more than $90 \%$ of all pupils, German by some $40 \%$, and French by less than $30 \%$.

Even though there are no legal obstacles to teach through the medium of Frisian, it is seldom done. In 1999, 1\% of all secondary schools reported regular use of Frisian as a medium of instruction. Another $30 \%$ would use it every now and then, and $69 \%$ never use Frisian to teach other subjects. It should not come as a surprise that the Inspectorate 
(Inspectie van het Onderwijs 1999: 8) concludes that "Frisian as a subject counts for little in the linguistic and cultural development of the students."

Mergers in secondary vocational education led to the establishment of three large Regional Training Centers, which offer a wide range of courses. Although there is no legal requirement for any subject to be taught, Dutch is always on the curriculum and English is usually on it, too, but it is rather exceptional when Frisian is taught. There are only a few possibilities for taking a subject related to Frisian. For instance, the economics and administration sector includes a training course for secretaries where Frisian can be chosen as a subject.

The Regional Training Centers also provide adult education courses. Some of these are courses on Dutch as a second language for migrants. Frisian can be used as an element of a literacy course. But most courses make little use of Frisian in their programs (Noordermeer and Renkema 1995). Outside these large centers there is the $A f \hat{u} k$, a separate and independent educational institute that specializes in Frisian classes for adults. The courses on offer vary from basic courses for learning to understand and read Frisian to more advanced courses in writing and literature. The Afûk also has a task in the production and publication of Frisian learning materials and children's books. Each year, around 1,000 people attend a Frisian language class. In Fryslân there are also several private or commercial institutes active that offer a wide variety of (language) courses, but they operate all over the Netherlands.

At tertiary level there are three institutes of professional training in Ljouwert. They offer a wide range of courses. As a rule, Dutch is the language of instruction in tertiary education in the Netherlands. All three institutes have a so-called "language statute" in which the exceptions (e.g. using English or Frisian) are specified. There is a trend to provide more and more courses through the medium of English in order to attract students from abroad. Strictly speaking, Frisian is almost always allowed in oral exams or in writing a thesis, but in practice the use of Frisian is very exceptional.

\subsection{Educational policy}

To comprehend the position of Frisian in schools one needs some understanding of the Dutch educational policy. The Dutch system combines a centralized education policy with the decentralized administration and management of schools. The state government controls education by means of legislation and regulations across both public and private 
schools. All schools, public and private, are governed by a legally recognized competent authority (school board). The state Inspectorate has to monitor the practice of education. The provincial government of Fryslân has a minor advisory role on Frisian matters in education. This includes the authority to rule on exemptions from the obligation to teach Frisian in primary schools ( $2 \%$ of schools have this exemption). The provincial government tries to encourage the teaching of Frisian at all levels of education through language-promotion activities on a modest scale (Plan fan oanpak 2001).

There are few central rules on language use in education, where Dutch is taken for granted as the language of instruction. The only exceptions in the law are that, in the province of Fryslân, Frisian has to be a subject in all primary schools, Frisian has to be taught in basic education in secondary schools, and Frisian has to be offered by teacher-training colleges in Fryslân. It can also be used as a medium of instruction.

Local authorities are responsible for preschool education. But none of the 31 municipalities has developed an explicit language policy, not even if they have a language policy in other domains. The preschool organizations are free in their choice of languages, but none of them have developed a written language policy either (Boneschansker and Le Rütte 2000). The way Frisian is dealt with can be described as "follow the leader": if children speak Frisian, in principle, they will be responded to in Frisian (except when the leader cannot speak Frisian). The few Frisian playgroups are the exception. There is no early introduction of a third language at this level.

Since 1980, all primary schools have been obliged by law to have Frisian on the curriculum. Schools are, in theory, free to determine the time they devote to any subject, thus also to Frisian. In all grades Frisian is permitted as medium of instruction.

The Ministry of Education has set compulsory attainment targets for the teaching of Frisian. The targets describe in detail which skills have to be attained in Frisian by the end of primary school. The Frisian targets are an exact mirror of those for the Dutch language. This implies that the educational program of the primary schools in the province should reach full bilingualism for all students, but that is just theory. As the volume of teaching for Frisian is far less than for Dutch, it does not come as a surprise that the results for Frisian lag behind (De Jong and Riemersma 1994).

In practice, the autonomy to fill the curriculum is restricted in many ways, and the Ministry of Education is notorious for its mania for organization. Educational policy is centrally developed to a very great degree. Frisian is not an important value for the ministry or its civil servants, but 
rather a marginal affair. This has hardly changed at all over the past seventy years (Hemminga 2000). School teachers who want to increase the number of Frisian lessons or the number of hours taught through Frisian are not stimulated by the authorities but, rather, discouraged.

Nonbinding guidelines for secondary education have been formulated which describe the attainment targets for the teaching of Frisian in "basic education." These guidelines for Frisian correspond to the obligatory targets set for the teaching of Dutch. It will be clear that it is impossible to attain such targets when the language is only taught one hour a week for one year (forty lessons). The new curriculum was introduced in 1993, but implementation of the teaching of Frisian is slow. During the school year 1997-1998, twelve of a total of 32 schools still had an exemption (Inspectie van het Onderwijs 1999).

\subsection{Teaching conditions}

Two tertiary institutes provide training to become a primary-school teacher. One of them also provides training for secondary-school teachers in a whole range of subjects, including Dutch, Frisian, and "modern languages." The duration of both types of course is four years and leads to a Bachelor's (BA) degree. In total, there are almost 1,500 students in teacher training for primary schools and a total of 2,000 students for all the different secondary school subjects, some fifteen among them for Frisian.

At both institutes, most students for primary-school teaching do obtain the certificate for Frisian. In terms of course time, this represents only one-eighth of the program, which does not guarantee an adequate or satisfactory command of the Frisian language.

The most important teaching method on the primary level is the Fryske Taalrotonde ("Frisian roundabout"). The method is based on communicative principles and aims at an integrative approach to the teaching of Frisian and Dutch. The language course can be used continuously from grade 1 (age 4) through grade 8 (age 12). Completion of the full course results in meeting the attainment targets for Frisian. Because there was a serious shortage of suitable and up-to-date learning material, some 400 of the 500 primary schools in Fryslân were quick to buy this method. A major problem, however, is that two-thirds of the teachers who work with the method reported that they use only part of the material (Le Rütte 1998). Frequently the teachers select those parts that suit them best at any given moment, which is not conducive to a continuous learning line.

At secondary level, teaching material is scarcer. There is only one language course (Flotwei Frysk), based on the model of a widely-used 
method for Dutch. Most teachers ( $82 \%$ ) use the course, but they frequently use other materials as well. Of course, there are several methods for the teaching of English, German, and French. These are the same as in the rest of the Netherlands.

In terms of its approach and teaching strategies of the trilingual schools, Ytsma (2000b: 6) states: "the Frisian multilingual project is based on three principles mentioned by Cummins in relation to successful bilingual schooling. These principles are (a) additive bilingualism, (b) linguistic interdependence and (c) interactive pedagogy." He goes on to explain that, according to the principle of additive bilingualism, learning a second language is not at the expense of the first language. For the Trilingual Schools Project this means that Frisian as the minority language must be supported, not only as a school subject, but also by using it extensively as medium of instruction. Frisian and Dutch are taught for equal amounts of time. English as a third language will be taught for more hours than is currently common in the primary schools in Fryslân (Meestringa 1987). The ideas behind linguistic interdependence imply that transfer of language proficiency easily occurs between typologically related languages such as Dutch, English, and Frisian. In the project, use is made of transfer when, for instance, learning to read is not taught two or three times separately per language, but in only one language - as an underlying ability which is the same for all three languages. A trilingual primary school is not to be considered as a school that teaches three languages, but as an integrated "language school." Finally, language learning has to take place on the basis of functional and meaningful communication, which is the basis for an interactive pedagogy.

In terms of new technologies it can be pointed out that, in addition to or instead of the Fryske Taalrotonde, there are special Frisian school television programs (usually broadcast once a week), which are supported by attractive learning material. Some of the "TV stars" have become popular among the target audiences (specific age groups of primary and lower secondary schools). So far, there are no special programs for the trilingual schools. In terms of computer-aided instruction, there are a number of English and Dutch programs that the schools can have at their disposal. So far, there is no software for learning Frisian; neither is there an integrated method.

\subsection{Results}

It should not come as a surprise that overall results for Frisian are poor given its marginal position. The study by the Inspectorate (Inspectie van 
het Onderwijs 2001: 28) concluded that only $26 \%$ of all primary schools have an offering of Frisian sufficient to reach the attainment targets. It might be worthwhile to further study these schools in order to find out how they could establish a sufficient number of hours of Frisian where the majority of schools fail to do so. A broad evaluation study by De Jong and Riemersma (1994) had already demonstrated that the results for different aspects of proficiency in Frisian are far below a desirable level of competence. In particular, pupils lag behind in technical reading, communicative speaking and writing. The quality of Frisian has also been examined as part of the same project (Ytsma 1995). The conclusion was that several aspects of the Frisian linguistic system seem to be changing among primary-school students - not just the lexical items but also syntactic (word order), morphological (diminutive forms), and phonological items (diphthongs change to monophthongs). The level of proficiency in Dutch can be considered average or good, both for Frisian-speaking and Dutch-speaking children, compared to national results (De Jong and Riemersma 1994: 244). The level of English at the end of primary school in Fryslân is estimated to be comparable to that of schools elsewhere in the Netherlands (Edelenbos et al. 2000).

In the Trilingual Schools Project, the position of English is different. On an experimental basis the schools have made use of teacher trainees from Northern Ireland, who are monolingual English-speakers. A smallscale study has shown that the children (aged 10-12) can manage well with an English monolingual teacher. The children have been asked whether they liked the English lessons taught by a teacher "from abroad." Of all children, $92 \%$ answered they liked it a (very) great deal. But when asked how difficult it was, $31 \%$ of the children said it was difficult to understand the English teacher. Ytsma (2003: 34) suggests that the English teachers could improve themselves on that point - for instance by speaking more slowly or by using simpler vocabulary.

The attitude of all primary-school teachers in Fryslân toward the different languages in primary school shows an interesting shift between 1988 and 1999. Frisian scored "very important" among $45 \%$ of the teachers in 1988 and $51 \%$ in 1999; thus a small increase. This contrasts with the results for English. In 1988, only 25\% considered English to be very important, a figure that doubled by 1999 to $52 \%$. The scores for Dutch did not change at all. Dutch scored 100\% both times (Inspectie van het Onderwijs 2001). In both cases, there has not been a change in terms of the numbers of hours that each of these languages are taught. The figures show an attitude shift in the direction of a much more favorable attitude toward English in the primary schools. It shows that there is support for the wider introduction of English at the primary level. 
The teachers have also been asked to judge the motivation of their pupils for learning the three languages. Between 1988 and 1999 the presupposed motivation for Frisian did not change. As both studies showed, teachers estimated that some $30 \%$ of the students were "strongly motivated" toward Frisian and 33\% were "not motivated" toward Frisian. For English the figures are quite different. The teachers estimated that some $80 \%$ were "strongly motivated" and only around $2 \%$ were unmotivated (Inspectie van het Onderwijs 1999).

The parents of the pupils in the Trilingual Schools Project have been asked several questions about their language attitudes (Haijtema 2000). The results of this study are that $100 \%$ of the parents see Dutch as a (very) important subject, $70 \%$ say the same about Frisian and $80 \%$ about English. 95\% of parents are of the opinion that knowledge of Frisian is useful for schoolchildren in Fryslân, and $70 \%$ have the same opinion about knowledge of English. Of these parents, 55\% evaluate using English as a medium of instruction for one additional subject positively, and $28 \%$ have a negative opinion. The model of using the same amounts of time for Dutch and Frisian was endorsed by $40 \%$, but rejected by $46 \%$. The latter category usually would like to see more Dutch. Overall, the conclusion of this study can be that a number of parents still have to be convinced of the advantages of the trilingual model in which their children participate.

\subsection{Challenges and problems}

Fishman (1991: 180-181) points out that the basic problem in Fryslân is to activate the passive goodwill for Frisian. He observes that the Frisian scene is rather lethargic compared to that of the Basques. Also Cummins (1989: 17) has made similar remarks concerning the apathy surrounding bilingual education in Fryslân.

The general attitude toward Frisian is ambivalent, whereas the attitudes toward English seem positive. Frisian may be appreciated for its historical value or as language of intimate contacts, but it is also regarded as of low value for economic purposes. Moreover, Frisian is not perceived to be endangered. The choice for Frisian in daily life may regularly lead to small language conflicts; so far, there has not been any discussion about the increased use of English. Parents and teachers only see a limited role for education in the process of preservation and promotion of the Frisian language. Today, most people may be convinced of the "harmless" character of teaching some Frisian, because it is not detrimental to 
Dutch, but they do not see the need for learning Frisian better. Few individuals see the advantages of high levels of multilingual competence in a regional, a national, and an international language: Frisian, Dutch, and English. This poses a challenge for the actors involved in the experiment with trilingual primary education. The model could be expanded to include more primary schools. Perhaps an earlier introduction of English would work to "sell" the concept of a language school to more parents and school boards.

Another challenge will come at the moment when the first secondary school starts with an English stream. The developments in the rest of the Netherlands make it clear that this will happen soon. That moment could also be an opportunity to secure a better place for Frisian. At tertiary level, English has been making inroads rapidly. It has already weakened the position of Dutch, and Frisian takes an insignificant place there. The challenge is to raise the awareness of the importance of linguistic diversity and language learning, particularly in the departments of teacher training.

For the children, raising their level of proficiency in Frisian, especially their literacy, is increasingly becoming problematic, perhaps more than for their proficiency in English. One impression is that the children are confronted with English outside the school from an early age and, frequently, that they will not have great problems in mastering that language as a second or third language. Their proficiency in Frisian, however, deteriorates because of the intensive contact and the social pressure of Dutch.

The development of adequate, up-to-date and modern language material for Frisian is faced with the problem of the costs involved. Acquiring English-language material is comparatively easy and less costly. The same applies for modern technological applications that can be used for language learning. There are hardly any computer-assisted languagelearning programs for Frisian, whereas there are scores of such programs for learning English.

\section{Conclusion}

Sometimes, from an outsider's perspective, it may seem as if arrangements for Frisian in education are satisfactory. After all, there is a reasonable legal framework and a number of adequate infrastructural provisions. However, from an insider's perspective, a concerned teacher or a policy-maker will tell a different story. One often hears complaints about 
the implementation of Frisian provisions. Even after the severe criticism of the Inspectorate (Inspectie van het Onderwijs 1999) and an international Commission of Experts of the Council of Europe (2001) things have hardly moved at all. The provincial authorities have entered into a new formal agreement with the state (Bestuursafspraak 2001) and also published a plan to improve Frisian in education (Plan fan oanpak 2001), but few steps have been taken. Policy development is a slow process, implementation of the plans even slower. In these circumstances it appears to be hard to bring about a change. Immersion education in Frisian, comparable with what is found among several other minority languages in Europe, is not legally precluded, but still seems unattainable. The experiment with trilingual education takes a middle position among other projects in Europe (Beetsma 2001).

The way Frisian is currently being taught confirms the place that Frisian holds in society. Schools do not work for the emancipation of the Frisian language, but rather play a conservative role (Gorter 1997).

These conclusions paint a bleak picture of the future for Frisian in education. The picture for English as an additional language looks much brighter. Many accept it almost eagerly as a language of international prestige and communication. In tertiary education, there was some discussion perhaps ten years ago, but this has waned. The Netherlands now scores very high in a comparative European perspective on the use of English as a medium of instruction in the universities. In secondary education, the number of bilingual English-Dutch schools is growing rapidly. It will not be long before such a model in Fryslân is also implemented. New developments will probably also lead to a lowering of the age at which the teaching of English in primary schools begins. Now, it is around the age of ten or eleven, but recent European recommendations propose the age of eight. One experiment with an early start, at the age of four, has already begun in The Hague.

Multilingualism in society is growing. Children no longer have Frisian, Dutch, or a dialect as a home language. Many children come from Frisian-Dutch mixed-language families. Furthermore, an increasing number of children speak a language from abroad as a first language. The language background of students becomes more heterogeneous. Thus, educational practice is becoming complicated and faces the challenge to integrate this multilingualism in the curriculum in an adequate way. The teaching of Frisian vis-à-vis other languages, notwithstanding its obvious weaknesses, remains an interesting case for sociolinguistic studies and research into multilingual language acquisition. 


\section{References}

Benton, R.; and Benton, N. (2001). RLS in Aotearoa/New Zealand. In Can Threatened Languages be Saved? Reversing Language Shift: A 21st Century Perspective, J. A. Fishman (ed.), 423-450. Clevedon: Multilingual Matters.

Beetsma, D. (ed.) (2001). Trilingual Primary Education in Europe. Inventory of the Provisions for Trilingual Primary Education in Minority Language Communities of the European Union. Ljouwert: Mercator-Education.

Bestuursafspraak (2001). Derde Bestuursafspraak Friese taal en cultuur 2001-2010. Den Haag/Ljouwert: Provinsje Fryslân.

Boneschansker, E.; and Le Rütte, M. (2000). Pjuttepraat. Friestaligheid in peuterspeelzalen en kinderdagverblijven. Ljouwert: Economisch Bureau Coulon.

Bremmer, R. H. (1997). Het ontstaan van het Fries en het Hollands. In Negen eeuwen Friesland-Holland, P. H. Breuker and A. Janse (eds.), 67-76. Zutphen: Fryske Akademy/ Walburg Pers.

Commission of Experts (2001). Application of the Charter in the Netherlands. Report of the Committee of Experts on the Charter. Strasbourg: Council of Europe ECRML (2001) 1.

Cummins, J. (1989). Language and literacy acquisition in bilingual contexts. Journal of Multilingual and Multicultural Development 10, 17-31.

De Jong, S.; and Riemersma, A. M. J. (1994). Taalpeiling yn Fryslân. Onderzoek naar de beheersing van het Fries en het Nederlands aan het einde van de basisschool. Ljouwert: Fryske Akademy.

Edelenbos, P.; Van der Schoot, F.; and Verstralen, H. (2000). Balans van het Engels aan het einde van de basisschool 2. Uitkomsten van de tweede peiling in 1996. Arnhem: Citogroep. http://download.citogroep.nl/pub/po/ppon/engels/balans17.pdf (02/12/2003).

Eurobarometer (2001). Europeans and Languages. Eurobarometer report 54. Brussels: Inra Europe ECO. http://europa.eu.int/comm/education/languages/lang/barolang_en.pdf $(02 / 12 / 2003)$.

Fishman, J. A. (1991). Reversing Language Shift. Theoretical and Empirical Foundations of Assistance to Threatened Languages. Clevedon: Multilingual Matters.

Fryslân yn sifers (2001). Fryslân yn sifers/Fryslân in cijfers 2001. Ljouwert: Provinsje Fryslân (also: http://www.fryslân.nl [12/02/2003]).

Gorter, D. (1997). Bilingual education in Friesland. In Encyclopedia of Language and Education, vol. 5: Bilingual Education, J. Cummins and D. Corson (eds.), 117-125. Dordrecht: Kluwer.

-(2001). A Frisian update of reversing language shift. In Can Threatened Languages be Saved? Reversing Language Shift: A 21st Century Perspective, J. A. Fishman (ed.), 215233. Clevedon: Multilingual Matters.

-; and Jonkman, R. J. (1995). Taal yn Fryslân: op e nij besjoen. Ljouwert: Fryske Akademy.

—; Jelsma, G. H.; van der Plank, P. H.; and de Vos, K. (1984). Taal in Fryslân. Ljouwert: Fryske Akademy.

-; Riemersma, A. M. J.; and Ytsma, J. (2001). Frisian in the Netherlands. In The Other Languages of Europe, G. Extra and D. Gorter (eds.), 103-118. Clevedon: Multilingual Matters.

Haijtema, F. (2000). Onderzoek attitude leerlingen en ouders drietalige school. Ljouwert: Fryske Akademy.

Hemminga, P. (2000). Het beleid inzake unieke regionale talen. Ljouwert: Fryske Akademy. Inspectie van het Onderwijs (1999). Fries in de basisvorming. Evaluatie van de eerste vijf jaar. Utrecht: Inspectie van het Onderwijs. 
-(2001). Het onderwijs Fries in op de basisscholen in Friesland ... de stand van zaken. Den Haag: Sdu Grafisch Bedrijf bv.

Lebecq, S. (1994). Fryske keaplju en seefarders yn de iere midsieuen. Ljouwert: Fryske Akademy.

Le Rütte, M. (1998). Evaluaasje Fryske taalrotonde. Ljouwert: Fryske Akademy.

Meestringa, T. (1987). English as a foreign language in Frisian bilingual primary schools. International Journal of the Sociology of Language 64, 59-71.

Nielsen, H. F. (1994). Ante Old Frisian. Nowele 24, 91-136.

Noordermeer, M.; and Renkema, W. J. (1995). Meartaligens yn de basisedukaasje yn Fryslân/Meertaligheid in de basiseducatie in Friesland. Leeuwarden: Fryske Akademy.

Plan fan oanpak (2001). Plan fan oanpak Frysk yn it ûnderwiis. Ljouwert: Provinsje Fryslân.

Pietersen, L. (1969). De Friezen en hun taal. Drachten: Laverman.

Projektplan (1997). Projektplan de 3-talige skoalle. Ljouwert: GCO fryslân/Fryske Akademy.

Van der Avoird, T.; Bontje, D.; Broeder, P.; Extra, G.; Muis, R.; and Peijs, N. (1999). Meertaligheid in Leeuwarden. De status van allochtone talen thuis en op school. Tilburg / Utrecht: Babylon / Sardes.

Van der Vaart, J. (2001). De wenjende Fries. In De aktuele steat fan Fryslân, P. Hemminga (ed.), 11-37. Ljouwert/Leeuwarden: Fryske Akademy.

Vries, O. (1997). From Old Frisian to Dutch: the elimination of Frisian as a written language in the sixteenth century. In Language Minorities and Minority Languages, B. Synak and T. Wicherkiewicz (eds.), 239-244. Gdansk: Wydawnictwo Uniwersytetu Gdanskiego.

Ytsma, J. (1995). Frisian as First and Second Language. Sociolinguistic and SocioPsychological Aspects in the Acquisition of Frisian among Frisian and Dutch Primary School Children. Ljouwert: Fryske Akademy.

- (2000a). Trilingual primary education in Friesland. In English in Europe: The Acquisition of a Third Language, J. Cenoz and U. Jessner (eds.), 222-235. Clevedon: Multilingual Matters.

- (2000b). A trilingual project in primary education in Friesland, The Netherlands. The EuroCLIC 7, 6-7.

- (2002). An experiment with trilingual primary education in Friesland. In Trilingual Primary Education in Europe, D. Beetsma (ed.), 51-58. Ljouwert/Leeuwarden: MercatorEducation/Fryske Akademy.

-(2003). Trije talen op ien skoalle. Taal, Frysk Tematydskrift 3 (March), 34-37.

-; and van der Schaaf, A. (2001). Frisian. The Frisian Language in Education in the Netherlands, 3rd ed. Regional Dossier Series. Ljouwert/Leeuwarden: Mercator-Education/ Fryske Akademy.

Zondag, K. (ed.) (1982). Bilingual Education in Friesland. Frjentsjer/Franeker: Wever.

- (1993). The very beginning of the Frisian movement. International Journal of the Sociology of Language 100/101, 193-201. 